\title{
Comparative Distribution and Taxonomic Value of Cellular Fatty Acids in Thirty-Three Genera of Anaerobic Gram-Negative Bacilli
}

\author{
LILLIAN V. H. MOORE, ${ }^{*}$ DIANNE M. BOURNE, AND W. E. C. MOORE \\ Department of Anaerobic Microbiology, Virginia Polytechnic Institute and State University, \\ Blacksburg, Virginia 24061-0305
}

\begin{abstract}
Cellular fatty acid profiles were determined for species in $\mathbf{3 3}$ genera of anaerobic gram-negative bacilli and were confirmed to be a useful taxonomic tool. Most of the genera could be differentiated by visual inspection of their profiles. The three genus pairs that were most difficult to distinguish visually (Bacteroides and Prevotella, Pectinatus and Megamonas, and Serpulina and Bilophila) and the species of these genera were differentiated by the MIDI (Microbial ID, Inc.) identification system. Similarities in cellular fatty acid profiles may be correlated with similarities in other phenotypic characteristics, but more often there is no other obvious phenotypic relationship. Although medium components may not change the constituents detected or the ratios among the constituents detected for some species, identical medium changes may result in vast differences in the profiles obtained with other species. Thus, if a worker wishes to compare profiles of various taxa, it is essential that the same cultural and analytical conditions be used.
\end{abstract}

In 1968 Ifkovits and Ragheb (23) analyzed the cellular fatty acid (FA) compositions of anaerobic gram-negative rods isolated from rumen contents and concluded that similarities and differences in cellular FA composition could aid in identification, but these authors did not differentiate between families and genera. Since the original study of Ifkovits and Ragheb, there have been numerous reports detailing the cellular FAs of anaerobic gram-negative bacilli $(2,4,10,23,32,35,36,38,40$, $46,53,62,65)$. Most of these later reports focused on description or taxonomy of single species or the species of a single genus $(2,10,32,35,38,46)$ or on species restricted to certain ecological niches $(4,10,23,38,40,65)$, particularly the human oral cavity and the rumen.

Since the original investigation of Ifkovits and Ragheb in 1968 , the taxonomy and nomenclature of anaerobic gramnegative rods have changed considerably, particularly with regard to species formerly included in the genus Bacteroides (20). There are now 11 genera that have been described for the species formerly included in the genus Bacteroides, and 16 species are designated species incertae sedis (51). In the light of the newer taxonomy, Ifkovits and Ragheb probably would have interpreted their data differently.

Even though various growth conditions and analytical methods have been used by previous investigators, there is relatively good agreement among investigators for some taxa; however, researchers have obtained discrepant results for other taxa. Although the major cellular FAs of most genera that have been studied are distinct, there is general agreement that all species of the genus Bacteroides (as recently redefined) (51) and the genus Prevotella that have been tested produce the same major cellular FAs $(4,35,36,46)$.

For tested Bacteroides, Prevotella, Porphyromonas, and $\mathrm{Fu}$ sobacterium species isolated from humans $(4,32,35,36,46)$, the results of previous investigators are relatively uniform qualitatively with regard to the major cellular constituents, although there are differences in the amounts of the major constituents detected, as well as qualitative differences in

\footnotetext{
* Corresponding author. Phone: (703) 231-7110. Fax: (703) 231-
}

minor components. The results of previous investigators are less consistent for the genera Fibrobacter and Ruminobacter (23).

No information regarding cellular FA composition is available for several genera and for some species belonging to well-studied genera of anaerobic gram-negative rods. Indeed, the results of previous individual and combined reports do not encompass all species currently included in any genus that comprises more than one species.

In this study we analyzed the cellular FA compositions of genera of anaerobic gram-negative rods by using the same growth and analytical conditions so that the taxonomic value of cellular FA composition could be determined for this wide spectrum of organisms.

\section{MATERIALS AND METHODS}

Bacterial strains. The organisms that we tested are listed in Table 1. All of the test strains of a species were from different individuals or sources. Campylobacter species were included because this genus now includes species of obligate anaerobes. Capnocytophaga and Eikenella species were included because strains of species belonging to these genera may be obligately anaerobic upon initial isolation.

Characterization of strains. Fermentation, enzymatic, and antimicrobial agent susceptibility tests in prereduced media and polyacrylamide gel electrophoresis of soluble proteins were performed as described previously $(17,41)$.

Cellular FA analyses. Unless otherwise specified, for analysis of cellular FAs actively growing cultures were inoculated into tubes containing $10 \mathrm{ml}$ of prereduced anaerobically sterilized peptone-yeast extract-glucose (PYG) broth (17). The tubes were inoculated under oxygen-free carbon dioxide or under an oxygen-free gas mixture containing $10 \%$ carbon dioxide and $90 \%$ nitrogen. The tubes were closed with neoprene stoppers and were incubated at $37^{\circ} \mathrm{C}$. All subsequent sample preparation steps were done by using the same tubes closed with Teflon-lined screw caps in an aerobic atmosphere. The caps were removed for centrifugation.

Sedimented cells from cultures that had been incubated at $37^{\circ} \mathrm{C}$ for 18 to $24 \mathrm{~h}$ were used immediately or were frozen and 
TABLE 1. Strains used in analyses of cellular FAs

\begin{tabular}{|c|c|c|c|}
\hline \multirow[b]{2}{*}{ Taxon } & \multirow[b]{2}{*}{ Type $\operatorname{strain}^{a}$} & \multicolumn{2}{|c|}{ No. of other strains used in this study } \\
\hline & & $\begin{array}{c}\text { Homology strains } \\
\text { (reference[s]) }\end{array}$ & Other strains \\
\hline Anaerorhabdus furcosus & $3253 \rightarrow$ ATCC 25662 & 0 & 0 \\
\hline Anaerovibrio lipolytica & ATCC 33276 & 0 & 0 \\
\hline Bacteroides fragilis & $2553 \rightarrow$ ATCC 25285 & $36(25)$ & 59 \\
\hline Bacteroides caccae & ATCC 43185 & $16(30)$ & 3 \\
\hline Bacteroides distasonis & ATCC 8503 & $11(25)$ & 3 \\
\hline Bacteroides eggerthii & ATCC 27754 & $9(25)$ & 0 \\
\hline Bacteroides merdae & T4-1 $\rightarrow$ ATCC 43184 & $7(30)$ & 1 \\
\hline Bacteroides ovatus & ATCC 8483 & $18(25)$ & 7 \\
\hline Bacteroides stercoris & B5-21 $\rightarrow$ ATCC 43183 & $17(30)$ & 3 \\
\hline Bacteroides thetaiotaomicron & $5482 \rightarrow$ ATCC 29148 & $12(25)$ & 22 \\
\hline Bacteroides uniformis & ATCC 8492 & $7(25)$ & 37 \\
\hline Bacteroides vulgatus & ATCC 8482 & $10(25)$ & 15 \\
\hline Bilophila wadsworthia & $14946=$ ATCC 49260 & 0 & 6 \\
\hline Butyrivibrio fibrisolvens & $077 \leftarrow$ Bryant D1 = ATCC 19171 & 0 & 0 \\
\hline Campylobacter fetus subsp. fetus & ATCC 33248 & 0 & 14 \\
\hline Campylobacter fetus subsp. venerealis & ATCC 19438 & 0 & 4 \\
\hline Campylobacter coli & ATCC 33559 & 0 & 15 \\
\hline Campylobacter concisus & ATCC 33237 & 0 & 99 \\
\hline Campylobacter curvus & ATCC 35224 & $1(60)$ & 19 \\
\hline Campylobacter hyointestinalis & ATCC 35217 & 0 & 10 \\
\hline Campylobacter jejuni & ATCC 33560 & 0 & 18 \\
\hline Campylobacter lari & NCTC 11352 & 0 & 0 \\
\hline Campylobacter mucosalis & NCTC 11000 & 0 & 14 \\
\hline Campylobacter rectus & ATCC 33238 & 0 & 69 \\
\hline Campylobacter sputorum subsp. bubulus & ATCC 33562 & 0 & 8 \\
\hline Campylobacter sputorum subsp. sputorum & $\mathrm{S} 17 \rightarrow$ ATCC 35980 & 0 & 3 \\
\hline Campylobacter upsaliensis & ATCC 43954 & 0 & 1 \\
\hline Capnocytophaga ochracea & ATCC 27872 & 0 & 82 \\
\hline Capnocytophaga canimorsus & ATCC 35979 & 0 & 0 \\
\hline Capnocytophaga cynodegmi & ATCC 49044 & 0 & 0 \\
\hline Capnocytophaga gingivalis & ATCC 33624 & 0 & 80 \\
\hline Capnocytophaga sputigena & ATCC 33612 & 0 & 64 \\
\hline Catonella morbi & ATCC 51271 & 0 & 7 \\
\hline Centipeda periodontii & ATCC 35019 & 0 & 0 \\
\hline Desulfomonas pigra & ATCC 29098 & 0 & 0 \\
\hline Dialister pneumosintes & ATCC 33048 & 0 & 52 \\
\hline Dichelobacter nodosus & ATCC 25549 & 0 & 1 \\
\hline Eikenella corrodens & $8499 \leftarrow$ Jackson $333=$ ATCC 23834 & 0 & 71 \\
\hline Fusobacterium nucleatum subsp. nucleatum & $4355 \rightarrow$ ATCC 25586 & $5(26)$ & 87 \\
\hline Fusobacterium nucleatum subsp. polymorphum & ATCC 10953 & $5(26)$ & 90 \\
\hline Fusobacterium nucleatum subsp. vincentii & ATCC 49256 & $14(26)$ & 88 \\
\hline Fusobacterium alocis & D40B-5 $\rightarrow$ ATCC 35896 & 0 & 50 \\
\hline Fusobacterium gonidiaformans & $0482 \mathrm{~A} \rightarrow$ ATCC 25563 & 0 & 26 \\
\hline Fusobacterium mortiferum & ATCC 25557 & 0 & 18 \\
\hline Fusobacterium naviforme & $5658 \rightarrow$ ATCC 25832 & 0 & 23 \\
\hline Fusobacterium necrogenes & $2368 \rightarrow$ ATCC 25556 & 0 & 1 \\
\hline Fusobacterium necrophorum subsp. necrophorum & $2891 \rightarrow$ ATCC 25286 & 0 & 61 \\
\hline Fusobacterium necrophorum subsp. funduliforme & $6161 \rightarrow \mathrm{JCM} 3724$ & 0 & 2 \\
\hline Fusobacterium perfoetens & ATCC 29250 & 0 & 0 \\
\hline Fusobacterium periodonticum & ATCC 33963 & 0 & 17 \\
\hline Fusobacterium russii & $0307 \rightarrow$ ATCC 25533 & 0 & 9 \\
\hline Fusobacterium ulcerans & & 0 & $6^{b}$ \\
\hline Fibrobacter succinogenes & ATCC 19169 & 0 & 0 \\
\hline Hallella seregens & ATCC 51272 & 5 & 0 \\
\hline Johnsonella ignava & ATCC 51276 & 0 & 10 \\
\hline Leptotrichia buccalis & ATCC 14201 & 0 & 56 \\
\hline Megamonas hypermegas & ATCC 25560 & 0 & 8 \\
\hline Mitsuokella multiacida & $8951=$ ATCC 27723 & 0 & 0 \\
\hline Oribaculum catoniae & ATCC 51270 & 0 & 58 \\
\hline Porphyromonas asaccharolytica & $4198 \rightarrow$ ATCC 25260 & 0 & 14 \\
\hline Porphyromonas endodontalis & $13912=$ ATCC 35406 & 0 & 5 \\
\hline Porphyromonas gingivalis & ATCC 33277 & 0 & 40 \\
\hline Porphyromonas salivosa & NCTC 11632 & 0 & 0 \\
\hline Prevotella melaninogenica & $2381 \rightarrow$ ATCC 25845 & $8(19,65)$ & 49 \\
\hline Prevotella bivia & $6822 \rightarrow$ ATCC 29303 & $12(18)$ & 6 \\
\hline
\end{tabular}


TABLE 1 -Continued

\begin{tabular}{|c|c|c|c|}
\hline \multirow[b]{2}{*}{ Taxon } & \multirow[b]{2}{*}{ Type strain ${ }^{a}$} & \multicolumn{2}{|c|}{ No. of other strains used in this study } \\
\hline & & $\begin{array}{l}\text { Homology strains } \\
\text { (reference[s]) }\end{array}$ & Other strains \\
\hline Prevotella buccae & D3A-6 $\rightarrow$ ATCC 33574 & $13(21)$ & 15 \\
\hline Prevotella buccalis & NCFB 2354 & 0 & 3 \\
\hline Prevotella corporis & $9342 \rightarrow$ ATCC 33547 & $6(28)$ & 0 \\
\hline Prevotella denticola & ATCC 35308 & $15(19,65)$ & 35 \\
\hline Prevotella disiens & $8057 \rightarrow$ ATCC 29426 & $9(18)$ & 2 \\
\hline Prevotella heparinolytica & ATCC 35895 & 0 & 9 \\
\hline Prevotella intermedia & $4197 \rightarrow$ ATCC 25611 & $12(28)$ & 23 \\
\hline Prevotella loescheii & ATCC 15930 & $6(19)$ & 49 \\
\hline Prevotella nigrescens & $8944 \rightarrow$ ATCC 33563 & $10(28,54)$ & 72 \\
\hline Prevotella oralis & D27B-24 $\rightarrow$ ATCC 33269 & $1(64)$ & 18 \\
\hline Prevotella oris & ATCC 33573 & $7(21)$ & 44 \\
\hline Prevotella oulora & ATCC 43324 & 0 & 0 \\
\hline Prevotella ruminocola subsp. ruminicola & 0051B $\rightarrow$ ATCC 19189 & 0 & 0 \\
\hline Prevotella veroralis & D22A-7 $\rightarrow$ ATCC 33779 & $4(64,65)$ & 12 \\
\hline Prevotella zoogleoformans & ATCC 33285 & 0 & 4 \\
\hline Rikenella microfusus & ATCC 29728 & 0 & 0 \\
\hline Ruminobacter amylophilus & ATCC 29744 & 0 & 0 \\
\hline Selenomonas sputigena & D19B-28 (sic) $\rightarrow$ ATCC 35185 & $3(29)$ & 81 \\
\hline Selenomonas artemidis & D22B-14 $\rightarrow$ ATCC 43528 & $5(38)$ & 32 \\
\hline Selenomonas dianae & D19A-11 $\rightarrow$ ATCC 43527 & $2(38)$ & 20 \\
\hline Selenomonas flueggeii & E4M-28B $\rightarrow$ ATCC 43531 & $13(38)$ & 49 \\
\hline Selenomonas infelix & D75B-30 $\rightarrow$ ATCC 43532 & $6(38)$ & 79 \\
\hline Selenomonas noxia & ATCC 43541 & $12(38)$ & 78 \\
\hline Selenomonas ruminantium subsp. ruminantium & ATCC 12561 & 0 & 1 \\
\hline Selenomonas ruminantium subsp. lactilytica & ATCC 19205 & 0 & 1 \\
\hline Serpulina hyodysenteriae & $\mathrm{V}-78=\mathrm{ATCC} 27164$ & 0 & 2 \\
\hline Serpulina innocens & $\mathrm{B} 256=\mathrm{ATCC} 29796$ & 0 & 0 \\
\hline Serpulina species "J" & & 0 & $12^{c}$ \\
\hline Succinimonas amylolytica & ATCC 19206 & 0 & 0 \\
\hline Succinivibrio dextrinosolvens & $0554 \rightarrow$ ATCC 19716 & 0 & 1 \\
\hline Tissierella praeacuta & ATCC 25539 & 0 & 4 \\
\hline Treponema denticola & & 0 & 15 \\
\hline Treponema pectinovorum & D36DR2 $\rightarrow$ ATCC 33768 & 0 & 0 \\
\hline Treponema socranskii subsp. buccale & D2B8 $\rightarrow$ ATCC 35534 & 0 & 0 \\
\hline Treponema socranskii subsp. paredis & D46CPE1 $\rightarrow$ ATCC 35535 & 0 & 0 \\
\hline Treponema socranskii subsp. socranskii & DR56BR1116 $\rightarrow$ ATCC 35536 & 0 & 0 \\
\hline "Treponema vincentii"" & & 0 & 1 \\
\hline
\end{tabular}

${ }^{a}$ Strains were obtained from the Moores' Virginia Polytechnic Institute and State University Culture Collection unless designated otherwise. ATCC, American Type Culture Collection, Rockville, Md.; JCM, Japanese Collection of Microorganisms, Saitama, Japan; NCFB, National Collection of Food Bacteria, Reading, United Kingdom (formerly National Collection of Dairy Organisms); NCTC, National Collection of Type Cultures, London, England. $\rightarrow$, deposited in; $\leftarrow$, received from.

${ }^{b}$ Strains were received from B. Adriaans, who described the species. One strain probably is the type strain, but no culture collection catalog gives Adriaan's number for the type strain, so we cannot be sure.

" Isolated from feces of AIDS patients.

later thawed. The cells were lysed and saponified with $1.0 \mathrm{ml}$ of basic methanol $(45 \mathrm{~g}$ of $\mathrm{NaOH}, 150 \mathrm{ml}$ of methanol, $150 \mathrm{ml}$ of deionized water), heated in a boiling water bath for $5 \mathrm{~min}$, mixed with a vortex mixer, and heated in the boiling water bath for an additional $25 \mathrm{~min}$. To methylate cell constituents, $1 \mathrm{ml}$ of HCl-methanol $(325 \mathrm{ml}$ of $6.0 \mathrm{~N} \mathrm{HCl}, 275 \mathrm{ml}$ of methanol [certified grade]) and $1 \mathrm{ml}$ of sulfuric acid-methanol $(162.5 \mathrm{ml}$ of $\mathrm{H}_{2} \mathrm{SO}_{4}$ [American Chemical Society reagent grade] added to $162.5 \mathrm{ml}$ of deionized water, $275 \mathrm{ml}$ of methanol [certified grade]) were added, and the solution was heated at $80^{\circ} \mathrm{C}$ for 10 min. After rapid cooling, the methylated components were extracted by adding $1.25 \mathrm{ml}$ of hexane-ether $(200 \mathrm{ml}$ of hexane [high-performance liquid chromatography grade], $200 \mathrm{ml}$ of methyl-tert butyl ether [high-performance liquid chromatography grade]) and turning the tubes end over end for $10 \mathrm{~min}$. Each extract was washed once with $3 \mathrm{ml}$ of a solution containing $5.4 \mathrm{~g}$ of $\mathrm{NaOH}$ in $450 \mathrm{ml}$ of deionized distilled water saturated with $\mathrm{NaCl}$. A $2-\mu \mathrm{l}$ portion of the washed extract was chromatographed on a fused-silica capillary column with a model HP-5890A chromatograph (Hewlett-Packard Co., Palo Alto, Calif.) equipped with a flame ionization detector and a model HP-3392A integrator (Hewlett-Packard). The gas flow rates were ca. $400 \mathrm{ml} / \mathrm{min}$ for air, $30 \mathrm{ml} / \mathrm{min}$ for hydrogen, and $30 \mathrm{ml} / \mathrm{min}$ for nitrogen. The temperatures used were $250^{\circ} \mathrm{C}$ for the injection port and $300^{\circ} \mathrm{C}$ for the detector. After injection, the oven temperature was increased from 170 to $270^{\circ} \mathrm{C}$ at a rate of $5^{\circ} \mathrm{C} / \mathrm{min}$ and then from 270 to $310^{\circ} \mathrm{C}$ at a rate of $30^{\circ} \mathrm{C} / \mathrm{min}$, held at $310^{\circ} \mathrm{C}$ for $2 \mathrm{~min}$, and then returned to $170^{\circ} \mathrm{C}$ before the next sample was injected. A standard mixture containing known FAs $\left(\mathrm{C}_{9}\right.$ through $\mathrm{C}_{20}$ straight-chain FAs and $2-\mathrm{OH} \mathrm{C} \mathrm{C}_{10}, 3-\mathrm{OH} \mathrm{C}_{10}, 2-\mathrm{OH} \mathrm{C} 14,3-\mathrm{OH} \mathrm{C} \mathrm{C}_{14}$, and 2-OH $\mathrm{C}_{16}$ FAs) was chromatographed at the beginning of each day on which samples were analyzed and after each set of 10 samples.

We used the MIS software package (Microbial ID, Inc., Newark, Del.) to identify the peaks (by retention time) and to determine the area, the ratio of area to height, the equivalent chain length (ECL), the total area, and the total area for named or listed compounds. The MIS software package also 
was used to calculate the percentage of area for each named or listed compound compared with the total area of the compounds detected. Compounds were identified by using the Moore Broth Library, version 3.8 (released in February 1994 by Microbial ID, Inc.).

For organisms that produced low turbidity in broth cultures, multiple $10-\mathrm{ml}$ cultures were pooled to obtain a larger cell pellet, and the extract was concentrated before analysis by evaporation under a stream of grade 5.0 nitrogen. Serum was not added to cultures because the FAs that occur in serum could not be removed from the cells by any wash reagent that we tested.

For strains of most species, one 10-ml PYG culture incubated overnight produced a sufficient pellet of sedimented cells to give a satisfactory extract for analysis. If a cell pellet larger than a flattened bead about $4 \mathrm{~mm}$ in diameter and $2 \mathrm{~mm}$ deep was produced (e.g., the pellets produced by Bacteroides fragilis cultures), some of the culture was discarded. The following conditions were used for strains that produced low turbidity in PYG cultures: for Bilophila strains, two to four 10-ml PYG cultures were incubated for 3 to 5 days, and the extract was concentrated; for Catonella strains, two to three PYG cultures were incubated for 3 to 4 days, and the extract was concentrated; for Dialister strains, four to six PYG cultures were incubated for 1 to 4 days, and the extract was concentrated; for Dichelobacter strains, four to six PYG cultures were incubated for 1 to 2 days, and the extract was concentrated; and for Johnsonella strains, two to four PYG cultures were incubated for 1 to 3 days, and the extract was concentrated. The cultures used for the Succinimonas library entry were grown in PYG medium with volatile FAs added (17), and the cultures used for the Desulfomonas entry were grown in pyruvate medium (17). For Butyrivibrio fibrisolvens, the results obtained with cells grown in media that did and did not contain volatile FAs (17) were combined for the reference library entry and for the information shown in Table 3. Only the results obtained with cells grown in PYG medium supplemented with volatile FAs were used for the data for Fibrobacter succinogenes shown in Table 2, but the results obtained with cells grown in media both with and without volatile FAs are given in Table 3 for Fibrobacter succinogenes.

To determine the cellular constituents that were representative of a genus, the amounts of constituents found in the different species of the genus (see above) were averaged. The amounts found in subspecies were averaged to obtain species values. The cellular constituent data for each species were derived from at least 20 analyses of the available strain(s) belonging to the species. Ideally, multiple strains were represented, but if only one strain was available, the results of multiple analyses of that strain, determined on different days and derived from different subcultures, were used to calculate the library entry.

\section{RESULTS AND DISCUSSION}

The analytical results are presented in Table 2. In Table 2, the taxa are arranged on the basis of similarity of cellular composition and are given reference numbers. All 33 genera studied could be differentiated by the MIDI identification system, and most could be differentiated visually by qualitative and quantitative differences in their cellular FA profiles. An example of the effects of different medium components (e.g., volatile FAs) on cellular FA composition is shown in Table 3. Some major phenotypic characteristics of the genera are shown in Table 4.

Despite the different culture conditions and analytical meth- ods used in various previous investigations and the diversity of strains studied, there was reasonably good agreement between our results and those of other authors for the genera Bacteroides $(2,4,35,36,46)$, Prevotella $(4,35,36,46)$, Porphyromonas $(4,32,35,36)$, Fusobacterium $(10,36)$, and Bilophila (2).

Our results for all 10 described Bacteroides species (Table 2, taxon 1) and 17 described Prevotella species (taxon 2) confirmed the previous findings $(2,35,36,46)$ that were based on up to five different Bacteroides species and up to six different Prevotella species namely, that anteiso- $\mathrm{C}_{15: 0}$, iso- $\mathrm{C}_{15: 0}$, iso3-OH $\mathrm{C}_{17: 0}$ and $\mathrm{C}_{16: 0}$ FAs are the major cellular FAs in these two genera. Among all anaerobic gram-negative rods, species belonging to the genera Bacteroides and Prevotella are the most similar in other phenotypic characteristics $(17,20,39)$. These two genera currently are differentiated by the inability of Prevotella strains to grow in the presence of $20 \%$ bile and by the production of glucose-6-phosphate dehydrogenase and 6-phosphogluconate dehydrogenase by Bacteroides species (52). The genus Prevotella corresponds to the second phylogenetic cluster delineated by Johnson and Harich (27), who observed 16 to $43 \%$ rRNA homology between Bacteroides species and species now recognized as members of the genus Prevotella.

Our results for 12 Fusobacterium species (taxon 14) are in general agreement with those of Calhoon et al. (10) and Miyagawa et al. (36), who studied representatives of eight and four Fusobacterium species, respectively. Major amounts of $\mathrm{C}_{14: 0}, \mathrm{C}_{16: 0}$, and $\mathrm{C}_{16: 1}$-cis 9 FAs distinguish the fusobacteria from the other genera tested. We did not include values for Fusobacterium prausnitzii and Fusobacterium sulci in our calculations for the genus Fusobacterium because these species probably should not be classified in this genus. The DNA of Fusobacterium prausnitzii has a much higher $\mathrm{G}+\mathrm{C}$ content $(52$ to $57 \mathrm{~mol} \%$ ) than the DNA of the type species, Fusobacterium nucleatum (27 to 28 mol\%) (43). Fusobacterium sulci tends to stain gram positive, and $14 \%$ of its cellular $\mathrm{FA}$ is $\mathrm{C}_{18: 1}$-cis 11 dimethyl acetal (DMA), in contrast to other species in this genus.

Our results for the genus Porphyromonas (taxon 5) were in general agreement with those of Mayberry et al. (35), Lambe et al. (32), Miyagawa et al. (36), Shah and Collins (46), and Brondz and Olsen (4). There is consensus that iso- $\mathrm{C}_{15: 0} \mathrm{FA}$ is the major FA in Porphyromonas strains, accounting for 33 to $58 \%$ of the FAs present. The next most common acid, which is present at a level of 10 to $20 \%$ and which we identified as either iso-3-OH $\mathrm{C}_{17}$ FA or $\mathrm{C}_{18: 2}$ DMA (ECLs, 18.163 and 18.178 , respectively) is probably the compound reported to be iso- $\mathrm{OH} \mathrm{C}_{17}$ FA by Lambe et al. (32), iso- $\mathrm{C}_{17} \mathrm{FA}$ by Miyagawa et al. (36), and iso-3-OH $\mathrm{C}_{17}$ FA by Brondz and Olsen (4).

Species belonging to the genera Porphyromonas (taxon 5), Capnocytophaga (taxon 4), and Rikenella (taxon 6) have similar FA profiles. The most distinctive difference among the cellular FAs of these three genera is in the relative amount of iso- $C_{15: 0}$ FA produced, which ranges from 36 to $55 \%$ (Table 2). The three genera are quite distinct on the basis of their phenotypic characteristics (Table 4). Porphyromonas species are nonsaccharolytic and produce acetate, propionate, isovalerate, isobutyrate, and succinate from peptone. Capnocytophaga and Rikenella species are saccharolytic and produce major amounts of acetic and succinic acids. Rikenella microfusus is obligately anaerobic and has a DNA G+C content of 60 to $61 \mathrm{~mol} \%$. Most Capnocytophaga strains are facultatively anaerobic (22) and have DNA G+C contents of 33 to $41 \mathrm{~mol} \%$.

Our results and those of Miyagawa et al. (36) for Anaerorhabdus (Bacteroides) furcosus (taxon 13) are in excellent agreement if the compounds that we differentiated as $C_{18: 1^{-}}$ 
TABLE 2. Cellular FA compositions of genera of anaerobic gram-negative rods

\begin{tabular}{|c|c|c|c|c|c|c|c|c|c|c|c|c|}
\hline & Taxon & & & & & & A composit & $\ln (\%)^{a}$ & & & & \\
\hline $\begin{array}{l}\text { Refer- } \\
\text { ence } \\
\text { no. }\end{array}$ & Genus & $\begin{array}{l}\text { Unknown } \\
\text { with ECL } \\
\text { of } 9.74\end{array}$ & $\begin{array}{l}\mathrm{C}_{11: 0} \\
\mathrm{FA}\end{array}$ & $\begin{array}{l}\mathrm{C}_{12: 0} \\
\mathrm{FA}\end{array}$ & $\begin{array}{c}\text { iso- } C_{13: 0} \\
F A\end{array}$ & $\begin{array}{l}\mathrm{C}_{13: 0} \\
\mathrm{FA}\end{array}$ & $\begin{array}{c}\text { iso- } C_{14: 0} \\
\text { FA }\end{array}$ & $\begin{array}{l}\mathrm{C}_{14: 0} \\
\mathrm{FA}\end{array}$ & $\begin{array}{l}C_{14: 0} \\
\text { DMA }\end{array}$ & $\begin{array}{c}\text { iso- } \mathrm{C}_{15: 0} \\
\mathrm{FA}\end{array}$ & $\begin{array}{c}\text { anteiso- } C_{15: 0} \\
\text { FA }\end{array}$ & $\begin{array}{l}\mathrm{C}_{15: 0} \\
\mathrm{FA}\end{array}$ \\
\hline 1 & Bacteroides & - & - & - & $\begin{array}{c}1 \\
(0-2)\end{array}$ & - & $\begin{array}{c}1 \\
(0-4)\end{array}$ & $\begin{array}{c}1 \\
(1-2)\end{array}$ & - & $\begin{array}{c}6 \\
(6-13)\end{array}$ & $\begin{array}{c}36 \\
(32-40)\end{array}$ & $\begin{array}{c}6 \\
(2-14)\end{array}$ \\
\hline 2 & Prevotella & - & - & - & $\begin{array}{c}1 \\
(0-5)\end{array}$ & - & $\begin{array}{c}5 \\
(0-13)\end{array}$ & $\begin{array}{c}2 \\
(0-9)\end{array}$ & - & $\begin{array}{c}10 \\
(4-18)\end{array}$ & $\begin{array}{c}35 \\
(22-45)\end{array}$ & $\begin{array}{c}1 \\
(0-3)\end{array}$ \\
\hline 3 & Oribaculum & - & - & 1 & 15 & - & - & 7 & 一 & 26 & 23 & 2 \\
\hline 4 & Capnocytophaga & - & - & - & $\begin{array}{c}1 \\
(0-3)\end{array}$ & - & - & $\begin{array}{c}1 \\
(0-2)\end{array}$ & - & $\begin{array}{c}55 \\
(45-70)\end{array}$ & $\begin{array}{c}4 \\
(1-8)\end{array}$ & $\begin{array}{c}1 \\
(0-3)\end{array}$ \\
\hline 5 & Porphyromonas & - & - & - & $\begin{array}{c}4 \\
(1-6)\end{array}$ & - & - & $\begin{array}{c}5 \\
(3-6)\end{array}$ & - & $\begin{array}{c}45 \\
(33-58)\end{array}$ & $\begin{array}{c}7 \\
(2-15)\end{array}$ & - \\
\hline 6 & Rikenella & - & - & - & 1 & - & - & 1 & - & 36 & - & 9 \\
\hline 7 & Tissierella & - & - & 2 & 4 & - & - & 14 & 2 & 24 & 5 & 1 \\
\hline 8 & Serpulina & $\begin{array}{c}2 \\
(1-2)\end{array}$ & - & - & - & - & - & $\begin{array}{c}2 \\
(2-2)\end{array}$ & $\begin{array}{c}2 \\
(0-3)\end{array}$ & $\begin{array}{c}14 \\
(11-16)\end{array}$ & $\begin{array}{c}2 \\
(1-2)\end{array}$ & $\begin{array}{c}2 \\
(1-3)\end{array}$ \\
\hline 9 & Bilophila & - & - & - & - & - & - & 6 & - & 17 & - & - \\
\hline 10 & Desulfomonas & - & - & - & - & - & - & 1 & - & 21 & - & - \\
\hline 11 & Butyrivibrio & - & - & 1 & - & - & - & 4 & 2 & - & - & - \\
\hline 12 & Dialister & - & - & 8 & - & - & - & 5 & - & - & - & - \\
\hline 13 & Anaerorhabdus & - & - & 1 & - & - & - & - & - & - & - & - \\
\hline 14 & Fusobacterium & - & - & $\begin{array}{c}3 \\
(1-10)\end{array}$ & - & - & - & $\begin{array}{c}22 \\
(11-44)\end{array}$ & $\begin{array}{c}3 \\
(0-11)\end{array}$ & - & - & 一 \\
\hline 15 & Treponema & - & - & $\begin{array}{c}2 \\
(0-5)\end{array}$ & - & $\begin{array}{c}1 \\
(0-2)\end{array}$ & $\begin{array}{c}4 \\
(0-6)\end{array}$ & $\begin{array}{c}19 \\
(12-31)\end{array}$ & $\begin{array}{c}7 \\
(3-12)\end{array}$ & - & $\begin{array}{c}4 \\
(0-8)\end{array}$ & $\begin{array}{c}9 \\
(3-15)\end{array}$ \\
\hline 16 & Succinimonas & - & - & 16 & - & - & - & 11 & - & - & - & 1 \\
\hline 17 & Succinivibrio & - & - & 1 & - & - & 一 & 20 & - & - & - & - \\
\hline 18 & Leptotrichia & - & - & 6 & - & - & - & 10 & - & - & - & 一 \\
\hline 19 & Campylobacter & - & - & $\begin{array}{c}3 \\
(0-10)\end{array}$ & - & - & - & $\begin{array}{c}9 \\
(5-14)\end{array}$ & - & - & - & $\begin{array}{c}1 \\
(0-19)\end{array}$ \\
\hline 20 & Ruminobacter & - & - & 4 & - & - & - & 13 & - & - & - & - \\
\hline 21 & Dichelobacter & - & - & 5 & - & - & - & 3 & - & - & - & - \\
\hline 22 & Eikenella & - & - & 7 & - & - & - & 2 & - & - & - & - \\
\hline 23 & Anaerobiospirillum & - & - & 3 & - & - & - & 3 & - & - & - & - \\
\hline 24 & Hallella & - & - & - & - & - & 15 & 11 & - & - & 5 & 1 \\
\hline 25 & Fibrobacter & - & - & - & - & - & 3 & 19 & 8 & - & 2 & 2 \\
\hline 26 & Catonella & - & - & 3 & - & - & - & 42 & 14 & - & - & - \\
\hline 27 & Johnsonella & 45 & - & - & - & - & - & 8 & - & - & - & - \\
\hline 28 & Selenomonas & - & $\begin{array}{c}5 \\
(4-7)\end{array}$ & $\begin{array}{c}3 \\
(2-4)\end{array}$ & - & $\begin{array}{c}11 \\
(3-17)\end{array}$ & - & $\begin{array}{c}2 \\
(1-4)\end{array}$ & $\begin{array}{c}17 \\
(10-22)\end{array}$ & - & - & $\begin{array}{c}13 \\
(9-17)\end{array}$ \\
\hline 29 & Centipeda & - & 4 & 1 & - & 14 & - & 1 & 17 & - & - & 21 \\
\hline 30 & Pectinatus & - & 11 & - & - & 4 & - & 1 & 18 & - & - & 21 \\
\hline 31 & Megamonas & - & 11 & - & - & - & - & - & 21 & - & - & 18 \\
\hline 32 & Anaerovibrio & - & 5 & 3 & - & 4 & - & - & 11 & - & - & 8 \\
\hline 33 & Mitsuokella & - & - & 12 & - & - & - & 7 & - & - & - & - \\
\hline
\end{tabular}

${ }^{a}$ Mean percentages of the total acids. - or 0 , less than $0.5 \%$ of total acids. The values in parentheses are ranges of values for species in the genera. The compounds included are those compounds that occurred at levels of $10 \%$ or more in one or more of the species. ECL, equivalent chain length.

cis 9 FA and $\mathrm{C}_{18: 1}$-cis $11 / \mathrm{t} 9 / \mathrm{t} 6 \mathrm{FA}$ or an unknown having an ECL of 17.824 (combined percentage, $46 \%$ [Table 2]) are equivalent to the $50 \%$ of $\mathrm{C}_{18: 1}$-cis 9 FA reported by Miyagawa et al.

Our results agreed only moderately well with those previously reported for the genera Ruminobacter (taxon 20) $(23,36)$, Fibrobacter (taxon 25) (23, 36), Butyrivibrio (taxon 11) (23), and Desulfomonas (taxon 10) (62). We agree with Ifkovits and Ragheb (23) and Miyagawa et al. (36) that $\mathrm{C}_{16: 0}(31 \%), \mathrm{C}_{18: 1}$ (14 and 19\%), and $\mathrm{C}_{14: 0}(13 \%)$ are the major FAs found in cells of Ruminobacter (Bacteroides) amylophilus. In addition to differences in the percentages detected, there also are differences concerning the precise identity of the $\mathrm{C}_{18: 1}$ compound found by the three different sets of investigators. Ifkovits and Ragheb (23) reported that $\mathrm{C}_{18: 1}$ FA was present at a concentration $22.5 \%$, Miyagawa et al. (36) reported that $\mathrm{C}_{18: 1}$-cis $7 \mathrm{FA}$ was present at a concentration of $27 \%$, and we found that
$\mathrm{C}_{18: 1}$-cis $9 \mathrm{FA}$ was present at a concentration of $14 \%$ and either $\mathrm{C}_{18: 1^{-}}$cis 11/t9/t6 FA or an unidentified compound with an ECL of 17.834 was present at a concentration of $19 \%$. Although these differences might be attributed to the different growth media used (VL-carbohydrate medium was used by the other two groups of workers; PYG medium was used in this study), it is more logical to presume that the differences are due to improved technology that enables more precise separation and identification of eluted methylated compounds. The $14 \%$ $\mathrm{C}_{18: 1}$-cis 9 FA helps differentiate the genus Ruminobacter from other genera that contain major amounts of $C_{16: 0}$ and $C_{14: 0}$ FAs.

For Fibrobacter (Bacteroides) succinogenes (taxon 25), we confirmed the finding of Miyagawa et al. (36) that $C_{16: 0}$ and $\mathrm{C}_{14: 0} \mathrm{FAs}$ are major cell constituents. However, we did not detect the major amount of $\mathrm{C}_{15: 0} \mathrm{FA}$ reported by both 
TABLE 2-Continued

\begin{tabular}{|c|c|c|c|c|c|c|c|c|c|c|c|c|c|c|}
\hline \multicolumn{15}{|c|}{ FA composition $(\%)^{a}$} \\
\hline $\begin{array}{l}\text { iso-C } \mathrm{C}_{16: 0} \\
\text { FA }\end{array}$ & $\begin{array}{c}\mathrm{C}_{16: 1^{-}} \\
\text {cis } \\
\mathrm{FA}\end{array}$ & $\begin{array}{c}\mathrm{C}_{16: 1}-c i s 9 \\
\mathrm{FA}\end{array}$ & $\begin{array}{l}\mathrm{C}_{16: 0} \\
\mathrm{FA}\end{array}$ & $\begin{array}{l}\mathrm{C}_{16: 0} \\
\text { DMA }\end{array}$ & $\begin{array}{c}\text { iso-C }_{17: 0} \\
\text { FA }\end{array}$ & $\begin{array}{l}\mathrm{C}_{18: 1} \text { DMA } \\
\text { (ECL, } \\
17.25)\end{array}$ & $\begin{array}{c}3-\mathrm{OH} \\
\mathrm{C}_{16: 0} \\
\mathrm{FA}\end{array}$ & $\begin{array}{c}\mathrm{C}_{18: 1}-c i s 9 \\
\mathrm{FA}\end{array}$ & $\begin{array}{l}\mathrm{C}_{18: 0} \\
\mathrm{FA}\end{array}$ & $\begin{array}{l}C_{18: 1} \\
\text { cis 11 } \\
\text { DMA }\end{array}$ & $\begin{array}{c}\mathrm{C}_{15: 0} \\
\text { DMA or } \\
\text { 3-OH } \\
\mathrm{C}_{14: 0} \mathrm{FA}\end{array}$ & 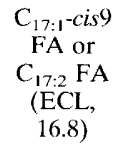 & $\begin{array}{c}\mathrm{C}_{18: 1}-1^{-c i s} 11 / \\
\mathrm{t} 9 / \mathrm{t} 6 \mathrm{FA} \text { or } \\
\text { unknown } \\
\text { with } \mathrm{ECL} \\
\text { of } 17.834\end{array}$ & $\begin{array}{c}\text { iso-3-OH } \\
\mathrm{C}_{17 ; 01} \mathrm{FA} \\
\text { or } \mathrm{C}_{18: 2} \\
\text { DMA }\end{array}$ \\
\hline $\begin{array}{c}1 \\
(0-2)\end{array}$ & - & $\begin{array}{c}1 \\
(0-4)\end{array}$ & $\begin{array}{c}9 \\
(6-12)\end{array}$ & - & $\begin{array}{c}2 \\
(0-6)\end{array}$ & - & $\begin{array}{c}4 \\
(2-6)\end{array}$ & - & - & - & - & - & - & $\begin{array}{c}15 \\
(11-19)\end{array}$ \\
\hline $\begin{array}{c}3 \\
(0-9)\end{array}$ & - & - & $\begin{array}{c}9 \\
(2-24)\end{array}$ & - & $\begin{array}{c}3 \\
(0-9)\end{array}$ & - & $\begin{array}{c}5 \\
(1-13)\end{array}$ & $\begin{array}{c}1 \\
(0-3)\end{array}$ & - & - & - & - & - & $\begin{array}{c}11 \\
(5-18)\end{array}$ \\
\hline- & - & 1 & 5 & - & 2 & - & 1 & 1 & - & - & - & - & - & 5 \\
\hline- & - & $\begin{array}{c}1 \\
(0-1)\end{array}$ & $\begin{array}{c}6 \\
(3-8)\end{array}$ & - & $\begin{array}{c}3 \\
(1-8)\end{array}$ & - & $\begin{array}{r}5 \\
(4-5)\end{array}$ & $\begin{array}{c}2 \\
(0-7)\end{array}$ & - & - & - & - & - & $\begin{array}{c}13 \\
(10-18)\end{array}$ \\
\hline- & - & $\begin{array}{c}1 \\
(0-1)\end{array}$ & $\begin{array}{c}9 \\
(4-13)\end{array}$ & - & $\begin{array}{c}1 \\
(1-1)\end{array}$ & - & $\begin{array}{r}3 \\
(1-5)\end{array}$ & $\begin{array}{c}1 \\
(1-2)\end{array}$ & $\begin{array}{c}1 \\
(0-1)\end{array}$ & - & - & - & - & $\begin{array}{c}15 \\
(10-20)\end{array}$ \\
\hline- & - & 1 & 7 & - & 1 & - & 1 & 8 & 4 & - & - & - & 1 & 15 \\
\hline - & - & 4 & 19 & 8 & 2 & - & - & 2 & 3 & - & - & - & - & - \\
\hline- & - & $\begin{array}{c}1 \\
(1-2)\end{array}$ & $\begin{array}{c}31 \\
(26-37)\end{array}$ & $\begin{array}{c}3 \\
(2-4)\end{array}$ & $\begin{array}{c}2 \\
(1-3)\end{array}$ & - & $\begin{array}{r}1 \\
(0-2)\end{array}$ & $\begin{array}{c}6 \\
(2-9)\end{array}$ & $\begin{array}{c}8 \\
(5-12)\end{array}$ & - & - & - & - & - \\
\hline - & - & 2 & 26 & 7 & 1 & - & 2 & 8 & 7 & - & - & - & 2 & - \\
\hline- & - & 13 & 30 & 3 & 21 & - & - & 1 & 3 & - & - & - & 1 & - \\
\hline 1 & - & 1 & 45 & 11 & - & - & - & 2 & 3 & 15 & - & 3 & 4 & - \\
\hline - & 2 & 11 & 20 & - & - & - & - & 21 & 12 & - & 8 & - & 2 & - \\
\hline- & 1 & 2 & 13 & 3 & - & - & - & 28 & 25 & - & - & - & 18 & - \\
\hline- & $\begin{array}{c}3 \\
(0-6)\end{array}$ & $\begin{array}{c}15 \\
(2-19)\end{array}$ & $\begin{array}{c}22 \\
(10-38)\end{array}$ & $\begin{array}{c}7 \\
(0-16)\end{array}$ & - & - & $\begin{array}{r}1 \\
(0-4)\end{array}$ & $\begin{array}{c}2 \\
(1-5)\end{array}$ & $\begin{array}{c}1 \\
(0-3)\end{array}$ & $\begin{array}{c}1 \\
(0-14)\end{array}$ & $\begin{array}{c}6 \\
(0-10)\end{array}$ & - & $\begin{array}{c}4 \\
(0-16)\end{array}$ & - \\
\hline $\begin{array}{c}4 \\
(0-6)\end{array}$ & - & $\begin{array}{c}1 \\
(0-1)\end{array}$ & $\begin{array}{c}21 \\
(14-29)\end{array}$ & - & - & - & - & $\begin{array}{c}4 \\
(0-7)\end{array}$ & $\begin{array}{c}4 \\
(0-7)\end{array}$ & - & - & - & - & - \\
\hline- & - & 3 & 37 & - & - & - & 8 & 3 & 2 & - & 3 & - & 13 & - \\
\hline- & - & 6 & 32 & - & - & - & 3 & 1 & 1 & - & 8 & - & 28 & - \\
\hline- & - & 2 & 42 & - & - & - & - & 1 & 1 & - & 8 & - & 28 & - \\
\hline- & - & $\begin{array}{c}9 \\
(5-16)\end{array}$ & $\begin{array}{c}29 \\
(24-40\end{array}$ & $\begin{array}{c}1 \\
(0-5)\end{array}$ & - & - & - & $\begin{array}{c}2 \\
(0-7)\end{array}$ & $\begin{array}{c}2 \\
(0-4)\end{array}$ & - & $\begin{array}{c}5 \\
(4-6)\end{array}$ & - & $\begin{array}{c}29 \\
(12-52)\end{array}$ & - \\
\hline- & - & 5 & 31 & 1 & - & - & 2 & 14 & 5 & - & 2 & - & $\begin{array}{c}(12-32) \\
19\end{array}$ & - \\
\hline- & - & 21 & 18 & - & - & - & - & 4 & 3 & - & 1 & 1 & 34 & - \\
\hline- & - & 15 & 24 & - & - & - & 1 & 7 & 6 & - & - & - & 27 & - \\
\hline- & - & 4 & 27 & - & - & - & - & 2 & 2 & - & 4 & - & 53 & - \\
\hline 15 & - & 2 & 23 & 1 & - & - & 16 & 3 & 2 & - & - & - & - & - \\
\hline 7 & - & 3 & 20 & - & - & - & - & 10 & 5 & - & - & - & 1 & - \\
\hline- & - & 2 & 12 & 1 & - & - & - & 5 & 4 & - & - & - & - & - \\
\hline- & - & 2 & 15 & 5 & - & - & - & 5 & 4 & 2 & - & - & 3 & 1 \\
\hline- & $\begin{array}{c}6 \\
(3-16)\end{array}$ & - & $\begin{array}{c}1 \\
(0-4)\end{array}$ & - & - & $\begin{array}{c}5 \\
(2-8)\end{array}$ & - & $\begin{array}{c}3 \\
(1-6)\end{array}$ & - & - & $\begin{array}{c}5 \\
(3-10)\end{array}$ & $\begin{array}{c}5 \\
(2-12)\end{array}$ & - & - \\
\hline- & 3 & - & - & - & - & 4 & - & 1 & - & - & 3 & 7 & - & - \\
\hline- & 3 & - & 2 & - & - & 12 & - & 2 & 1 & - & 1 & 9 & - & - \\
\hline- & 2 & - & 2 & - & - & 8 & - & 1 & 1 & - & 1 & 17 & - & - \\
\hline- & 6 & - & 1 & - & - & 8 & - & 3 & - & - & 4 & 18 & - & - \\
\hline- & 20 & 3 & 11 & 2 & - & - & - & 5 & 2 & - & 19 & - & - & - \\
\hline
\end{tabular}

Miyagawa et al. and Ifkovits and Ragheb (23) or the major amount of $\mathrm{C}_{13: 0}$ FA reported by Ifkovits and Ragheb. Miyagawa et al. reported the presence of $20 \% \mathrm{C}_{18: 0} \mathrm{FA}$; this compound accounted for only $5 \%$ of the acids that we detected and was not detected at all by Ifkovits and Ragheb. Ifkovits and Ragheb examined three strains obtained from Bryant that we have not examined, which might explain the different results. However, both Miyagawa et al. and we analyzed ATCC strain $19169^{\mathrm{T}}$ ( $\mathrm{T}=$ type strain), so the large differences between the results of Miyagawa et al. and our observations cannot be attributed to a misidentified strain and we are not able to explain them.

The only major difference between our results and those of Ifkovits and Ragheb (23) for Butyrivibrio fibrisolvens (taxon 11) is that Ifkovits and Ragheb found $12 \% \mathrm{C}_{18: 1} \mathrm{FA}$ and we found $2 \% \mathrm{C}_{18: 1}$-cis $9 \mathrm{FA}$ and $16 \% \mathrm{C}_{18: 1}$-cis 11 DMA, which were not found by Ifkovits and Ragheb. Since these two compounds have ECLs of 17.770 and 18.285 , respectively, it is unlikely that there was a problem in identification of the compounds. Both Ifkovits and Ragheb and we tested cultures derived from Bryant strain $\mathrm{D} 1^{\mathrm{T}}$. The culture medium used by Ifkovits and Ragheb contained volatile FAs, but we did not detect major differences when our strains of Butyrivibrio fibrosolvens were analyzed by using cells grown in media with and without added volatile FAs (Table 3 ).

For the type strain of Desulfomonas pigra (taxon 10), we agree with Vainshtein et al. (62) that about $20 \%$ of the acids is iso- $\mathrm{C}_{15: 0} \mathrm{FA}$. However, we found quantitative differences in the percentages of $\mathrm{C}_{16.0} \mathrm{FA}(30 \%$ in our study, $11 \%$ in the study of Vainshtein et al.), iso- $\mathrm{C}_{17: 0}$ FA (21\% in our study, $12 \%$ in the study of Vainshtein et al.), and $\mathrm{C}_{16: 1}$-cis 9 FA (13\% in our study, $6.5 \%$ in the study of Vainshtein et al.). We did not detect iso- $\mathrm{C}_{17: 0}$-cis $7 \mathrm{FA}$, which accounted for $26 \%$ of the cell constituents reported by Vainshtein et al. Although the ana- 
TABLE 3. Effect of the presence of volatile FAs in the growth medium on cellular FAs

\begin{tabular}{|c|c|c|c|c|}
\hline \multirow{3}{*}{ Compound } & \multicolumn{4}{|c|}{$\% \mathrm{in}^{a}:$} \\
\hline & \multicolumn{2}{|c|}{ Butyrivibrio fibrosolvens } & \multicolumn{2}{|c|}{ Fibrobacter succinogenes } \\
\hline & $\begin{array}{c}\text { With } \\
\text { volatile FAs }\end{array}$ & $\begin{array}{c}\text { Without } \\
\text { volatile FAs }\end{array}$ & $\begin{array}{c}\text { With } \\
\text { volatile FAs }\end{array}$ & $\begin{array}{c}\text { Without } \\
\text { volatile FAs }\end{array}$ \\
\hline $\mathrm{C}_{14: 0} \mathrm{FA}$ & 2 & 4 & 6 & 16 \\
\hline $\mathrm{C}_{15: 0}^{14.0} \mathrm{FA}$ & 0 & 0 & 47 & 1 \\
\hline $\mathrm{C}_{16: 0} \mathrm{FA}$ & 38 & 45 & 3 & 21 \\
\hline $\mathrm{C}_{16: 0} \mathrm{DMA}$ & 9 & 11 & 0 & 1 \\
\hline $\mathrm{C}_{18: 1}$ cis $9 \mathrm{FA}$ & 1 & 2 & 1 & 14 \\
\hline $\mathrm{C}_{18: 1}$ cis 11 DMA & 19 & 15 & 0 & 0 \\
\hline
\end{tabular}

${ }^{a}$ Percentage of the total chromatogram area for each compound. The values in each column do not add up to $100 \%$ because only acids that were present at levels at $>10 \%$ in either of the species are listed.

lytical method used by Vainshtein et al. was similar to our method in that the MIDI identification system was used, Vainshtein et al. used a chemically defined growth medium with an oxidized sulfur compound as the electron acceptor, which probably explains the rather large difference in the cellular FAs detected. Our results agreed with those of Baron et al. (2), who also used growth in a complex medium for analysis.

For the genera Megamonas, Mitsuokella, Succinimonas, and Succinivibrio, agreement was relatively poor between our results and the results reported by other workers. In cells of Megamonas hypermegas (taxon 31), we detected $21 \% \quad \mathrm{C}_{14: 0}$ DMA, which was not reported by Miyagawa et al. (36), and did not detect a compound reported to have an ECL of 19.21 that was present at a concentration of $17 \%$ in the study of Miyagawa et al. The cellular constituents of the genus Pectinatus (taxon 30) were similar to those of the genus Megamonas qualitatively, but there were quantitative differences in the major components (Table 2). Although species belonging to both genera produce major amounts of propionic acid, Pectinatus strains are motile by means of lateral flagella and Megamonas strains are not motile (Table 4).

For Mitsuokella multiacidus (taxon 33), the major differences between our results and those of Miyagawa et al. were as follows: we detected $12 \% \mathrm{C}_{12: 0} \mathrm{FA}$, a compound not detected by Miyagawa et al. (36), and we detected only $3 \% \mathrm{C}_{16: 1}$-cis 9 FA, compared with the $32 \%$ reported by Miyagawa et al. Mitsuokella multiacidus was the only species in this study in which we detected major amounts of $\mathrm{C}_{16: 1}$-cis7 FA (20\%) and $\mathrm{C}_{15: 0}$ DMA or 3-OH C $\mathrm{1}_{\text {14:0 }}$ FA (19\%).

In strain N6 of Succinimonas amylolytica (taxon 16), Ifkovits and Ragheb (23) detected 53\% iso- $\mathrm{C}_{15: 0}$ FA and $11 \%$ iso- $\mathrm{C}_{17: 0}$ FA; we detected neither of these compounds in cells of ATCC $19206^{\mathrm{T}}\left(=\right.$ Bryant strain $\left.\mathrm{B}_{2} 4^{\mathrm{T}}\right)$. Compared with the relatively good correlations for major compounds that we observed between our results and those of other authors for some other genera, we are at a loss to explain these major discrepancies.

Although both we and Ifkovits and Ragheb (23) found about $20 \% \mathrm{C}_{14: 0} \mathrm{FA}$ in the type strain of Succinivibrio dextrinosolvens (taxon 17), there were major differences in the other acids detected. Ifkovits and Ragheb detected $22 \%$ anteiso- $\mathrm{C}_{15: 0} \mathrm{FA}$, $11 \% \mathrm{C}_{15: 0} \mathrm{FA}$, and iso- $\mathrm{C}_{16: 0} \mathrm{FA}$, compounds that were not detected by us, whereas we detected $28 \% \mathrm{C}_{18: 1}$-cis $11 / \mathrm{t} 9 / \mathrm{t} 6 \mathrm{FA}$ or an unknown compound with an ECL of 17.834. Also, we detected $32 \% \mathrm{C}_{16: 0} \mathrm{FA}$, compared with the $7 \% \mathrm{C}_{16: 0} \mathrm{FA}$ detected by Ifkovits and Ragheb. The genus Anaerobiospirillum (taxon 23), another taxon that comprises motile gram-negative anaerobes that produce major amounts of succinic acid, has a distinct cell composition. Cells of the type strain of Anaerobiospirillum succiniciproducens also contain a compound identified as either $\mathrm{C}_{18: 1}$-cis $11 / \mathrm{t} 9 / \mathrm{t} 6 \mathrm{FA}$ or an unknown compound with an ECL of 17.8 , but at a much higher percentage $(53 \%)$. Among the genera included in this study, the presence of this compound at a concentration greater than $35 \%$ is unique to the genus Anaerobiospirillum.

Although the major acids of the genera Leptotrichia (taxon 18) and Campylobacter (taxon 19) are similar to those of the genus Succinivibrio qualitatively, there are quantitative differences that distinguish these taxa (Table 2). Phenotypically, these genera are differentiated by metabolic acid products, motility, and aerotolerance (Table 4).

The cellular composition of the genus Centipeda (taxon 29) is similar to the composition of the genus Selenomonas (taxon 28 ) that we reported previously (38); the two taxa differ principally in the relative amounts of $\mathrm{C}_{15: 0}$ FA. Members of these two genera and of the genus Pectinatus (taxon 30) also are similar phenotypically, differing in the location of flagella. The FA profile of the genus Anaerovibrio (taxon 32), another genus that comprises motile anaerobic gram-negative bacilli that produce major amounts of propionic acid, is similar to but distinct from the FA profiles of the genera Centipeda, Selenomonas, and Pectinatus (Table 2).

Three recently proposed (40) fermentative genera of obligately anaerobic gram-negative rods, the genera Oribaculum, Hallella, and Catonella, have unique fermentation profiles. Although the cellular FAs of the genus Oribaculum (taxon 3) are somewhat similar to those of the genera Bacteroides and Prevotella (Table 2), Oribaculum strains differ significantly in the amount of iso-C $\mathrm{C}_{13: 0} \mathrm{FA}$ (15 versus $1 \%$ ), and there are smaller differences in the amounts of iso- $\mathrm{C}_{15: 0} \mathrm{FA}$, anteiso$\mathrm{C}_{15: 0} \mathrm{FA}$, and iso-3-OH $\mathrm{C}_{17: 0} \mathrm{FA}$ or $\mathrm{C}_{18: 2}$ DMA produced. The genus Oribaculum is the only taxon included in this study that has a major amount of iso- $\mathrm{C}_{13: 0}$ FA. In addition to its different cellular FA profile, Oribaculum catoniae produces substantially more propionic acid and less succinic acid in PYG cultures than bacteroides or prevotella strains do (Table 4). Strains of the genus Hallella (taxon 24) contain $\mathrm{C}_{16: 0}$ and $\mathrm{C}_{14: 0}$ FAs, as do several other genera of anaerobic gram-negative bacilli. However, the major amounts of iso- $\mathrm{C}_{14: 0}$ FA (15\%) and iso- $\mathrm{C}_{16: 0}$ FA $(15 \%)$ produced by members of the genus Hallella are unique to this taxon. The major cellular FA of the genus Catonella (taxon 26) is $\mathrm{C}_{14: 0}$; the percentage of this acid is $42 \%$, which is the highest percentage of this acid found in any anaerobic, gram-negative, rod-shaped organism tested.

The two taxa of spirochetes analyzed, the genus Treponema (taxon 15) and the genus Serpulina (taxon 8), were less like each other than we expected. The genus Treponema (taxon 15) and the genus Fusobacterium (taxon 14) contain major amounts of $\mathrm{C}_{14: 0}$ and $\mathrm{C}_{16: 0} \mathrm{FAs}$, but Treponema cells do not contain the major amount of $\mathrm{C}_{16: 1}$-cis $9 \mathrm{FA}(15 \%)$ found in Fusobacterium cells. The cellular FA profile of the genus Serpulina (taxon 8 ) was most like that of the nonfermentative species Bilophila wadsworthia (taxon 9). Species of both genera produce major amounts of iso- $\mathrm{C}_{15: 0}$ and $\mathrm{C}_{16: 0} \mathrm{FAs}$; trace amounts of other constituents in the genus Serpulina differentiate the two taxa, which are quite distinct phenotypically (Table 4). A major amount (14\%) of $\mathrm{C}_{14: 0}$ FA produced by cells of the genus Tissierella (taxon 7) helps differentiate this taxon from the genera Serpulina and Bilophila.

The major cellular constituents of two genera of nonfermentative bacteria, the genera Dichelobacter (taxon 21) and Eikenella (taxon 22), are $\mathrm{C}_{16: 1}$-cis 9 FA, $\mathrm{C}_{16: 0} \mathrm{FA}$, and a compound that is either $\mathrm{C}_{18: 1}$ - cis $11 / \mathrm{t} 9 / \mathrm{t} 6 \mathrm{FA}$ or an unidentified 
TABLE 4. Some differential properties of taxa of anaerobic gram-negative bacilli

\begin{tabular}{|c|c|c|c|c|c|c|c|}
\hline \multicolumn{2}{|r|}{ Taxon } & \multirow{2}{*}{$\begin{array}{c}\mathrm{G}+\mathrm{C} \\
\text { content } \\
(\text { mol\%) }\end{array}$} & \multirow[b]{2}{*}{ Saccharolytic ${ }^{a}$} & \multirow{2}{*}{$\begin{array}{c}\text { Major } \\
\text { product(s) }\end{array}$} & \multirow[b]{2}{*}{ Motility ${ }^{a}$} & \multirow{2}{*}{$\begin{array}{c}\mathrm{O}_{2} \\
\text { tolerance }\end{array}$} & \multirow[b]{2}{*}{ Reference(s) } \\
\hline $\begin{array}{l}\text { Reference } \\
\text { no. }\end{array}$ & Genus & & & & & & \\
\hline 1 & Bacteroides & $40-48$ & + & S,A & - & An & 20,30 \\
\hline 2 & Prevotella & $36-52$ & + & $\mathrm{S}, \mathrm{A}$ & - & An & $39,52,53,54$ \\
\hline 3 & Oribaculum & 49 & + & $\mathrm{P}, \mathrm{a}, \mathrm{s}, \mathrm{l}$ & - & An & 40 \\
\hline 4 & Capnocytophaga & $33-41$ & + & S,A & - & F-An & 22 \\
\hline 5 & Porphyromonas & $46-51$ & - & $\mathrm{A}, \mathrm{B}, \mathrm{iV}$ & - & An & $20,34,50$ \\
\hline 6 & Rikenella & $60-61$ & w & $\mathrm{A}, \mathrm{S}, \mathrm{p}$ & - & An & 13,20 \\
\hline 7 & Tissierella & 28 & - & $\mathrm{A}, \mathrm{B}, \mathrm{iV}$ & - & An & 12,20 \\
\hline 8 & Serpulina & 26 & w & $a, b$ & + & An & 56,59 \\
\hline 9 & Bilophila & $39-40$ & - & A & - & An & 2 \\
\hline 10 & Desulfomonas & $66-67$ & - & a & - & An & 42 \\
\hline 11 & Butyrivibrio & $36-41$ & + & $\mathrm{B}(\mathrm{L})$ & + & An & 5 \\
\hline 12 & Dialister & $\mathrm{NR}^{d}$ & - & $\mathrm{a}(\mathrm{l}, \mathrm{p}, \mathrm{s})$ & - & An & 40 \\
\hline 13 & Anaerorhabdus & 34 & w & $\mathrm{L}, \mathrm{a}$ & - & An & 20,49 \\
\hline 14 & Fusobacterium & $26-34^{e}$ &,$- w$ & $\mathrm{~B}, \mathrm{a}(\mathrm{p}, \mathrm{f}, \mathrm{l})$ & - & An & $1,11,43,55$ \\
\hline 15 & Treponema ${ }^{f}$ & $36-51$ & v & $A(p, b)$ & + & An & 56 \\
\hline 16 & Succinimonas & NR & + & $\mathrm{S}, \mathrm{A}$ & + & An & 6 \\
\hline 17 & Succinivibrio & NR & + & $\mathrm{S}, \mathrm{A}, \mathrm{F}$ & + & An & 7 \\
\hline 18 & Leptotrichia & 25 & + & $\mathrm{L}$ & - & An & 16 \\
\hline 19 & Campylobacter & $30-38$ & - & None & + & $\mathrm{M}, \mathrm{An}$ & $3,15,45,57,61,63$ \\
\hline 20 & Ruminobacter & $40-42$ & + & $\mathrm{S}, \mathrm{A}, \mathrm{F}$ & - & An & 20,58 \\
\hline 21 & Dichelobacter & 45 & - & $\mathrm{a}, \mathrm{s}, \mathrm{p}$ & - & An & 14,20 \\
\hline 22 & Eikenella & $56-58$ & - & a & - & F-An & 24 \\
\hline 23 & Anaerobiospirillum & 44 & + & $\mathrm{S}, \mathrm{A}$ & + & An & 8 \\
\hline 24 & Hallella & 58 & + & $\mathrm{S}, \mathrm{a}, \mathrm{l}$ & - & An & 40 \\
\hline 25 & Fibrobacter & $47-49$ & + & A,S & - & An & 20,37 \\
\hline 26 & Catonella & 34 & + & A & - & An & 40 \\
\hline 27 & Johnsonella & 32 & - & $\mathrm{a}, \mathrm{iv}, \mathrm{l}, \mathrm{s}, \mathrm{ib}, \mathrm{i}$ & - & An & 40 \\
\hline 28 & Selenomonas & $54-61$ & + & $\mathrm{P}, \mathrm{A}$ & + & An & 9,38 \\
\hline 29 & Centipeda & 53 & + & $\mathrm{P}, \mathrm{A}$ & + & An & 31 \\
\hline 30 & Pectinatus & 40 & + & $\mathrm{P}, \mathrm{A}$ & + & An & 33 \\
\hline 31 & Megamonas & 35 & + & $\mathrm{P}, \mathrm{a}, \mathrm{l}, \mathrm{s}$ & - & An & 20,47 \\
\hline 32 & Anaerovibrio & NR & + & $\mathrm{P}, \mathrm{A}$ & + & An & 44 \\
\hline 33 & Mitsuokella & $56-58$ & + & $\mathrm{L}, \mathrm{S}, \mathrm{A}$ & - & An & 20,48 \\
\hline
\end{tabular}

${ }^{a}+$, positive reaction; - , negative reaction; $w$, weak reaction; $v$, variable among species.

${ }^{b} \mathrm{~A}$ and $\mathrm{a}$, acetic acid; $\mathrm{B}$ and $\mathrm{b}$, butyric acid; $\mathrm{F}$ and $\mathrm{f}$, formic acid; ib, isobutyric acid; $\mathrm{V}$ and iv, isovaleric acid; $\mathrm{L}$ and $\mathrm{I}, \mathrm{lactic}$ acid; $\mathrm{P}$ and $\mathrm{p}, \mathrm{propionic}$ acid; $\mathrm{S}$ and $\mathrm{s}$, succinic acid; uppercase letters, $>100 \mathrm{meq} / 100 \mathrm{ml}$ of culture; lowercase letters, $<100 \mathrm{meq} / 100 \mathrm{ml}$ of culture. The compounds in parentheses are compounds that are detected irregularly.

${ }^{c}$ An, anaerobic; F-An, facultatively anaerobic; M, microaerophilic.

${ }^{a} \mathrm{NR}$, not reported.

${ }^{e}$ Fusobacterium prausnitzii and Fusobacterium sulci not included.

${ }^{f}$ Cultivable strains.

compound with an ECL of 17.8. The FA profiles of the two taxa differ in the relative amounts of these constituents and in other constituents detected in trace to moderate amounts. The FAs of a third genus of non-fermentative organisms, the genus Dialister (taxon 12) (40), are unique (Table 2).

Of all of the genera of gram-negative rods that we have studied, the genus Johnsonella (40) has the most distinctive cellular FAs; $45 \%$ of the total chromatogram area for the products that were listed and detected represents an unidentified acid with an ECL of 9.740 (Table 2), and $15 \%$ is $\mathrm{C}_{16: 0}$ FA. The metabolic end products of members of the genus Johnsonella are different from those of members of the genera Porphyromonas, Tissierella, Desulfomonas, and Bilophila, which are other genera that contain nonfermentative organisms (Table 4). Of these, only the genus Tissierella contains organisms with a low $\mathrm{G}+\mathrm{C}$ content $(28 \mathrm{~mol} \%)(8)$ similar to the $\mathrm{G}+\mathrm{C}$ content of Johnsonella strains ( $32 \mathrm{~mol} \%)$.

Within genera that have multiple species, visual differentiation of cellular FA patterns among species often is difficult, if not impossible (data not shown), but the species can be distinguished by the MIDI identification system. If a worker wishes to use the MIDI identification system, it is essential that the media, incubation temperatures, and chromatography conditions used for the unknown cultures be the same as those used to develop the library entries. The effect of different media on cellular constituents described above (Table 3) is only one of many possible effects and was included to emphasize the importance of strict adherence to standard operating conditions if reproducible results and valid comparisons are to be made.

Because the major cellular constituents of species in a genus are relatively uniform (see range of variation in Table 2), they can be useful in indicating the genus to which organisms with characteristics unlike those of any described species might be assigned or in excluding unknown strains from particular genera.

\section{ACKNOWLEDGMENTS}

We gratefully acknowledge the help of Pauletta C. Atkins, Martina T. Bullard, Polly H. Cooper, Jane L. Hungate, Kathy H. Pennington, and Sue C. Smith in microbiological studies, Ann P. Donnelly in electrophoretic and chromatographic studies, and Claudine Saville for 
technical assistance. We appreciate critical reviews of the manuscript by J.-S. Chen and J. L. Johnson.

This work was supported by Program Project grant DE 08972 from the National Institute of Dental Research, National Institutes of Health, and by grant VA 135145 from the Cooperative State Research Service, U.S. Department of Agriculture.

\section{REFERENCES}

1. Adriaans, B., and H. Shah. 1988. Fusobacterium ulcerans sp. nov. from tropical ulcers. Int. J. Syst. Bacteriol. 38:447-448.

2. Baron, E. J., P. Summanen, J. Downes, M. C. Roberts, H. Wexler, and S. M. Finegold. 1989. Bilophila wadsworthia, gen. nov. and sp. nov., a unique gram-negative anaerobic rod recovered from appendicitis specimens and human faeces. J. Gen. Microbiol. 135: 3405-3411.

3. Benjamin, J., S. Leaper, R. J. Owens, and M. B. Skirrow. 1983. Description of Campylobacter laridis, a new species comprising the nalidixic acid resistant thermophilic Campylobacter (NARTC) group. Curr. Microbiol. 8:231-238.

4. Brondz, I., and I. Olsen. 1991. Multivariate analyses of cellular fatty acids in Bacteroides, Prevotella, Porphyromonas, Wolinella, and Campylobacter spp. J. Clin. Microbiol. 29:183-189.

5. Bryant, M. P. 1984. Butyrivibrio Bryant and Small 1956, 18, emend. Moore, Johnson and Holdeman 1976, 241 AL, p. 641-643. In N. R. Krieg and J. G. Holt (ed.), Bergey's manual of systematic bacteriology, vol. 1. The Williams \& Wilkins Co., Baltimore.

6. Bryant, M. P. 1984. Succinimonas Bryant, Small, Bouma and Chu 1958, 21 AL, p. 643-644. In N. R. Krieg and J. G. Holt (ed.), Bergey's manual of systematic bacteriology, vol. 1. The Williams \& Wilkins Co., Baltimore.

7. Bryant, M. P. 1984. Succinivibrio Bryant and Small 1956, $22^{\mathrm{AI}}$, p. 644-645. In N. R. Krieg and J. G. Holt (ed.), Bergey's manual of systematic bacteriology, vol. 1. The Williams \& Wilkins Co., Baltimore.

8. Bryant, M. P. 1984. Anaerobiospirillum Davis, Cleven, Brown and Balish 1976, 503 ${ }^{\text {AL }}$, p. 645-646. In N. R. Krieg and J. G. Holt (ed.), Bergey's manual of systematic bacteriology, vol. 1. The Williams \& Wilkins Co., Baltimore.

9. Bryant, M. P. 1984. Selenomonas Von Prowazek 1913, 36 ${ }^{\text {AL, }}$ p. 650-653. In N. R. Krieg and J. G. Holt (ed.), Bergey's manual of systematic bacteriology, vol. 1. The Williams \& Wilkins Co., Baltimore.

10. Calhoon, D. A., W. R. Mayberry, and J. Slots. 1983. Cellular fatty acid and soluble protein profiles of oral fusobacteria. J. Dent. Res. 62:1181-1185.

11. Cato, E. P., L. V. H. Moore, and W. E. C. Moore. 1985. Fusobacterium alocis sp. nov. and Fusobacterium sulci sp. nov. from the human gingival sulcus. Int. J. Syst. Bacteriol. 35:475-477.

12. Collins, M. D., and H. N. Shah. 1986. Reclassification of Bacteroides praeacutus Tissier (Holdeman and Moore) in a new genus, Tissierella, as Tissierella praeacuta comb. nov. Int. J. Syst. Bacteriol. 36:461-463.

13. Collins, M. D., H. N. Shah, and T. Mitsuoka. 1985. Reclassification of Bacteroides microfusus (Kaneuchi and Mitsuoka) in a new genus, Rikenella, as Rikenella microfusus comb. nov. Syst. Appl. Microbiol. 6:79-81.

14. Dewhirst, F. E., B. J. Paster, S. La Fontaine, and J. I. Rood. 1990. Transfer of Kingella indologenes (Snell and Lapage 1976) to the genus Suttonella gen. nov. as Suttonella indologenes comb. nov.; transfer of Bacteroides nodosus (Beveridge 1941) to the genus Dichelobacter gen. nov. as Dichelobacter nodosus comb. nov.; and assignment of the genera Cardiobacterium, Dichelobacter, and Suttonella to Cardiobacteriaceae fam. nov. in the gamma division of Proteobacteria on the basis of 16S rRNA sequence comparisons. Int. J. Syst. Bacteriol. 40:426-433.

15. Gebhart, C. J., P. Edmonds, G. E. Ward, H. J. Kirtz, and D. J. Brenner. 1985. "Campylobacter hyointestinalis" sp. nov.: a new species of Campylobacter found in the intestines of pigs and other animals. J. Clin. Microbiol. 21:715-720.

16. Hofstad, T. 1984. Leptotrichia Trevisan 1879, 138 ${ }^{\mathrm{AL}}$, p. 637-641. In N. R. Krieg and J. G. Holt (ed.), Bergey's manual of systematic bacteriology, vol. 1. The Williams \& Wilkins Co., Baltimore.

17. Holdeman, L. V., E. P. Cato, and W. E. C. Moore (ed.). 1977.
Anaerobe laboratory manual, 4th ed. VPI Anaerobe Laboratory, Blacksburg, $\mathrm{Va}$.

18. Holdeman, L. V., and J. L. Johnson. 1977. Bacteroides disiens sp. nov, and Bacteroides bivius sp. nov. from human clinical infections. Int. J. Syst. Bacteriol. 27:337-345.

19. Holdeman, L. V., and J. L. Johnson. 1982. Description of Bacteroides loescheii $\mathrm{sp}$. nov. and emendation of the descriptions of Bacteroides melaninogenicus (Oliver and Wherry) Roy and Kelly 1939 and Bacteroides denticola Shah and Collins 1981. Int. J. Syst. Bacteriol. 32:399-409.

20. Holdeman, L. V., R. W. Kelly, and W. E. C. Moore. 1984. Genus 1. Bacteroides Castellani and Chalmers $1919,959^{\mathrm{AL}}$, p. 604-631. In N. R. Krieg and J. G. Holt (ed.), Bergey's manual of systematic bacteriology, vol. 1. The Williams \& Wilkins Co., Baltimore.

21. Holdeman, L. V., W. E. C. Moore, P. J. Churn, and J. L. Johnson. 1982. Bacteroides oris and Bacteroides buccae, new species from human periodontitis and other human infections. Int. J. Syst. Bacteriol. 32:125-131.

22. Holt, S. C., and S. A. Kinder. 1989. Genus II. Capnocytophaga Leadbetter, Holt and Socransky $1982,266^{\mathrm{VP}}$, p. 2025-2058. In J. T. Staley, M. P. Bryant, N. Pfennig, and J. G. Holt (ed.), Bergey's manual of systematic bacteriology, vol. 3. The Williams and Wilkins Co., Baltimore.

23. Ifkovits, R. W. and H. S. Ragheb. 1968. Cellular fatty acid composition and identification of rumen bacteria. Appl. Microbiol. 16:1406-1413.

24. Jackson, F. L., and Y. Goodman. 1984. Eikenella Jackson and Goodman $1972,74^{\mathrm{AL}}$, p. 591-597. In N. R. Krieg and J. G. Holt (ed.), Bergey's manual of systematic bacteriology, vol. 1. The Williams \& Wilkins Co., Baltimore.

25. Johnson, J. L. 1978. Taxonomy of the bacteroides. I. Deoxyribonucleic acid homologies among Bacteroides fragilis and other saccharolytic Bacteroides species. Int. J. Syst. Bacteriol. 28:245256.

26. Johnson, J. L. Personal communication.

27. Johnson, J. L., and B. Harich. 1986. Ribosomal ribonucleic acid homology among species of the genus Bacteroides. Int. J. Syst. Bacteriol. 36:71-79.

28. Johnson, J. L., and L. V. Holdeman. 1983. Bacteroides intermedius comb. nov. and descriptions of Bacteroides corporis sp. nov. and Bacteroides levii sp. nov. Int. J. Syst. Bacteriol. 33:15-25.

29. Johnson, J. L., L. V. Holdeman, and W. E. C. Moore. 1985. Replacement of the type strain of Selenomonas sputigena under Rule 18g. Int. J. Syst. Bacteriol. 35:371-374.

30. Johnson, J. L., W. E. C. Moore, and L. V. H. Moore. 1986 Bacteroides caccae sp. nov., Bacteroides merdae sp. nov., and Bacteroides stercoris $\mathrm{sp}$. nov. isolated from human feces. Int. J. Syst. Bacteriol. 36:499-501.

31. Lai, C.-H., M. Males, P. A. Dougherty, P. Berthold, and M. A. Listgarten. 1983. Centipeda periodontii gen. nov., sp. nov. from human periodontal lesions. Int. J. Syst. Bacteriol. 33:628-635.

32. Lambe, D. W., Jr., K. P. Ferguson, and W. R. Mayberry. 1982. Characterization of Bacteroides gingivalis by direct fluorescent antibody staining and cellular fatty acid profiles. Can. J. Microbiol. 28:367-374.

33. Lee, S. Y. 1984. Pectinatus Lee, Mabee and Jangaard 1978, $582^{\mathrm{AL}}$, p. 655-658. In N. R. Krieg and J. G. Holt (ed.), Bergey's manual of systematic bacteriology, vol. 1. The Williams \& Wilkins Co., Baltimore.

34. Love, D. N., G. D. Bailey, S. Collings, and D. A. Briscoe. 1992 Description of Porphyromonas circumdentaria sp. nov. and reassignment of Bacteroides salivosus (Love, Johnson, Jones, and Calverley 1987) as Porphyromonas (Shah and Collins 1988) salivosa comb. nov. Int. J. Syst. Bacteriol. 42:434 438.

35. Mayberry, W. R., D. W. Lambe, Jr., and K. P. Ferguson. 1982 Identification of Bacteroides species by cellular fatty acid profiles. Int. J. Syst. Bacteriol. 32:21-27.

36. Miyagawa, E., R. Azuma, and T. Suto. 1979. Cellular fatty acid composition in gram-negative obligately anaerobic rods. J. Gen. Microbiol. 25:41-51

37. Montgomery, L., B. Flesher, and D. Stahl. 1988. Transfer of Bacteroides succinogenes (Hungate) to Fibrobacter gen. nov. as Fibrobacter succinogenes comb. nov. and description of Fibrobacter 
intestinalis sp. nov. Int. J. Syst. Bacteriol. 38:430-435.

38. Moore, L. V. H., J. L. Johnson, and W. E. C. Moore. 1987. Selenomonas noxia sp. nov., Selenomonas flueggei sp. nov., Selenomonas infelix sp. nov., Selenomonas dianae sp. nov., and Selenomonas artemidis sp. nov. from the human gingival crevice. Int. J. Syst. Bacteriol. 37:271-280.

39. Moore, L. V. H., and W. E. C. Moore. 1993. Anaerobe laboratory manual update, 1993. VPI Anaerobe Laboratory, Blacksburg, Va.

40. Moore, L. V. H., and W. E. C. Moore. 1994. Oribaculum catoniae gen. nov., sp. nov.; Catonella morbi gen. nov., sp. nov.; Hallella seregens gen. nov., sp. nov.; Johnsonella ignava gen. nov., sp. nov.; and Dialister pneumosintes gen. nov., comb. nov., nom. rev., anaerobic gram-negative bacilli from the human gingival crevice. Int. J. Syst. Bacteriol. 44:187-192.

41. Moore, W. E. C., D. E. Hash, L. V. Holdeman, and E. P. Cato. 1980. Polyacrylamide slab gel electrophoresis of soluble proteins for studies of bacterial floras. Appl. Environ. Microbiol. 39:900907.

42. Moore, W. E. C., and L. V. Holdeman. 1984. Genus Desulfomonas Moore, Johnson and Holdeman 1976, 238 AL, p. 672-673. In N. R. Krieg and J. G. Holt (ed.), Bergey's manual of systematic bacteriology, vol. 1. The Williams \& Wilkins Co., Baltimore.

43. Moore, W. E. C., L. V. Holdeman, and R. W. Kelley. 1984. Genus II. Fusobacterium Knorr 1922, $4^{\mathrm{AL}}$, p. 631-637. In N. R. Krieg and J. G. Holt (ed.), Bergey's manual of systematic bacteriology, vol. 1 . The Williams \& Wilkins Co., Baltimore.

44. Prins, R. A. 1984. Anaerovibrio Hungate $1966,80^{\mathrm{AL}}$, p. $653-655$. In N. R. Krieg and J. G. Holt (ed.), Bergey's manual of systematic bacteriology, vol. 1. The Williams \& Wilkins Co., Baltimore.

45. Sandstedt, K., and J. Ursing. 1991. Description of Campylobacter upsaliensis sp. nov. previously known as the CNW group. Syst. Appl. Microbiol. 14:39-45.

46. Shah, H. N., and M. D. Collins. 1980. Fatty acid and isoprenoid quinone composition in the classification of Bacteroides melaninogenicus and related taxa. J. Appl. Bacteriol. 48:75-87.

47. Shah, H. N., and M. D. Collins. 1982. Reclassification of Bacteroides hypermegas (Harrison and Hansen) in a new genus, Megamonas, as Megamonas hypermegas comb. nov. Zentralbl. Bakteriol. Parasitenkd. Infektionskr. Hyg. Abt. 1 Orig. Reihe C 3:394-389.

48. Shah, H. N., and M. D. Collins. 1982. Reclassification of Bacteroides multiacidus (Mitsuokella, Terada, Watanabe, and Uchida) in a new genus Mitsuokella, as Mitsuokella multiacidus comb. nov. Zentralbl. Bakteriol. Parasitenkd. Infektionskr. Hyg. Abt. 1 Orig. Reihe C 3:491-494.

49. Shah, H. N., and M. D. Collins. 1986. Reclassification of Bacteroides furcosus Veillon and Zuber (Hauduroy, Ehringer, Urbain, Guillot and Magrou) in a new genus Anaerorhabdus, as Anaerorhabdus furcosus comb. nov. Syst. Appl. Microbiol. 8:86-88.

50. Shah, H. N., and M. D. Collins. 1988. Proposal for reclassification of Bacteroides asaccharolyticus, Bacteroides gingivalis, and Bacteroides endodontalis in a new genus, Porphyromonas. Int. J. Syst. Bacteriol. 38:128-131.

51. Shah, H. N., and M. D. Collins. 1989. Proposal to restrict the genus Bacteroides (Castellani and Chalmers) to Bacteroides fragilis and closely related species. Int. J. Syst. Bacteriol. 39:85-87.
52. Shah, H. N., and M. D. Collins. 1990. Prevotella, a new genus to include Bacteroides melaninogenicus and related species formerly classified in the genus Bacteroides. Int. J. Syst. Bacteriol. 40:205208.

53. Shah, H. N., M. D. Collins, J. Watanabe, and T. Mitsuoka. 1985. Bacteroides oulorum sp. nov., a nonpigmented saccharolytic species from the oral cavity. Int. J. Syst. Bacteriol. 35:193-197.

54. Shah, H. N., and S. E. Gharbia. 1992. Biochemical and chemical studies on strains designated Prevotella intermedia and proposal of a new pigmented species, Prevotella nigrescens sp. nov. Int. J. Syst. Bacteriol. 42:542-546.

55. Slots, J., T. V. Potts, and P. A. Mashimo. 1983. Fusobacterium periodonticum, a new species from the human oral cavity. J. Dent. Res. 62:960-963.

56. Smibert, R. M. 1984. Treponema Schaudinn 1905, $1728^{\mathrm{AL}}$, p. 49-57. In N. R. Krieg and J. G. Holt (ed.), Bergey's manual of systematic bacteriology, vol. 1. The Williams \& Wilkins Co., Baltimore.

57. Smibert, R. M. 1984. Campylobacter Sebald and Véron 1963, $907^{\mathrm{AL}}$, p. 111-118. In N. R. Krieg and J. G. Holt (ed.), Bergey's manual of systematic bacteriology, vol. 1. The Williams \& Wilkins Co., Baltimore.

58. Stackebrandt, E., and H. Hippe. 1986. Transfer of Bacteroides amylophilus to a new genus Ruminobacter gen. nov., nom. rev. as Ruminobacter amylophilus comb. nov. Syst. Appl. Microbiol. 8:204-207.

59. Stanton, T. B. 1992. Proposal to change the genus designation of Serpula to Serpulina gen. nov. containing the species Serpulina hyodysenteriae comb. nov. and Serpulina innocens comb. nov. Int. J. Syst. Bacteriol. 42:189-190.

60. Tanner, A. C. R., M. A. Listgarten, and J. L. Eberson. 1984. Wolinella curva sp. nov.: "Vibrio succinogenes" of human origin. Int. J. Syst. Bacteriol. 34:275-282.

61. Tanner, A. C. R., and S. S. Socransky. 1984. Genus VIII. Wolinella Tanner, Badger, Listgarten, Visconti and Socransky 1981, 439 VP, p. 646-651. In N. R. Krieg and J. G. Holt (ed.), Bergey's manual of systematic bacteriology, vol. 1. The Williams \& Wilkins Co., Baltimore.

62. Vainshtein, M., H. Hippe, and R. M. Kroppenstedt. 1992. Cellular fatty acid composition of Desulfovibrio species and its use in classification of sulfate-reducing bacteria. Syst. Appl. Microbiol. 15:554-566.

63. Vandamme, P., E. Falsen, R. Rossau, B. Hoste, P. Segers, R. Tytgat, and J. De Ley. 1991. Revision of Campylobacter, Helicobacter, and Wolinella taxonomy: emendation of generic descriptions and proposal of Archobacter gen. nov. Int. J. Syst. Bacteriol. 41:88-103.

64. Watanabe, J., Y. Benno, and T. Mitsuoka. 1983. Taxonomic study of Bacteroides oralis and related organisms and proposal of Bacteroides veroralis sp. nov. Int. J. Syst. Bacteriol. 33:57-64.

65. Wu, C. C., J. L. Johnson, W. E. C. Moore, and L. V. H. Moore. 1992. Emended descriptions of Prevotella denticola, Prevotella loescheii, Prevotella veroralis, and Prevotella melaninogenica. Int. J. Syst. Bacteriol. 42:536-541. 